\title{
Escravidão, Quotidiano e Gênero na Emergente Capital Alagoana (1849-1888)
}

\begin{abstract}
Resumo:
Este presente artigo visa explanar sobre a escravidão em Maceió ao longo da segunda metade do século XIX. Para tanto, abordaremos o quotidiano como local de resistência de escravos e africanos livres perante a hegemonia senhorial. Como característica das cidades brasileiras oitocentistas, a presença da escravidão era marcante na vida social maceioense, tendo uma grande população de escravos, libertos, africanos livres e homens livres pobres circulando diariamente pelas ruas, becos e praças, fixando-se nos arredores da cidade, desenvolvendo seus arranjos de sobrevivência, buscando contrapor a hegemonia senhorial, delineando o viver urbano maceioense ao longo do século XIX. Dentro deste cenário, a presença de mulheres negras foi uma constante; elas teceram vivências nas ruas e praças da capital alagoana, compondo a paisagem urbana com seus costumes e inseridas num contexto de escravidão citadina. Desta maneira, foram fundamentais para a ordem doméstica e ao pequeno comércio.
\end{abstract}

Palavras-chaves: Escravidão, Quotidiano e Resistência.

\begin{abstract}
:
This present article aims to explain about slavery in Maceio during the second half of the nineteenth century. To do so, we discuss the everyday as a site of resistance of slaves and free Africans before the hegemony manor. Characteristic of nineteenth-century Brazilian cities, the presence of slavery was remarkable in social maceioense, having a large population of slaves, freedmen, free Africans and poor freemen circulating daily in the streets, alleys and squares, settling on the outskirts of the city, developing their arrangements, seeking survival counteract the hegemony manor, delineating urban living maceioense throughout the nineteenth century. Within this scenario, the presence of black women was a constant: they wove experiences in the streets and squares of the capital of Alagoas, composing the cityscape with its customs and inserted in a context of slavery city. Thus, were fundamental to the domestic order and small businesses.
\end{abstract}

Keywords: Slavery, Quotidian and Resistance.

\section{Maceió: uma cidade oitocentista}

Maceió, segundo informações do historiador Craveiro Costa, surgiu a partir de um engenho de açúcar situado às margens do riacho $M a c ̧ a y o^{2}$, durante o século XVIII. Foi estabelecido neste local em virtude da proximidade do porto marítimo de Jaraguá, para facilitar a exportação, principalmente para os portos de Recife e Salvador. (COSTA, 2001, p. 20). Elevada à categoria de vila, em 1815, Maceió viveu um surto de crescimento ao longo do século XIX, principalmente após 1839, quando se tornou capital da Província de Alagoas. Um fator importante neste processo foi a presença de uma burguesia mercantil formada por exportadores de açúcar, algodão3 e de madeiras de construção naval. Segundo Dirceu Lindoso, a realização urbana de Maceió se deu pela acumulação de capital pelo comércio marítimo, sobretudo, pela transferência da renda rural fundiária para as mãos hábeis da burguesia mercantil. (LINDOSO, 2005, p. 82).

\footnotetext{
${ }^{1}$ Graduado em História pela Universidade Federal de Alagoas e Mestre em História Social pela Pontifícia Universidade Católica de São Paulo com a dissertação Sobreviver e Resistir: os caminhos para liberdade de africanas livres e escravas em Maceió (1849-1888), sob orientação da Prof. ${ }^{a}$ Dra $^{\text {a }}$ Maria Odila Leite da Silva Dias.

2 Maçayo ou Maçaio-k é uma denominação tupi e significa "o que tapa o alagadiço".

3 Segundo informações de Moacir Sant'Ana, em Alagoas, a cana-de-açúcar era produzida principalmente em Atalaia, Imperatriz (atual União dos Palmares), Maceió, Passo do Camaragibe, Penedo, Porto Calvo, Porto das Pedras, Santa Luzia do Norte, São Miguel dos Campos, Viçosa e Cidade de Alagoas (atual Marechal Deodoro). Já o cultivo de algodão se dava em Anadia, Mata Grande, Palmeiras dos Índios, Traipu, Atalaia e Coruripe. (SANT'ANA, 1970, p. 110).
} 
Para o historiador Moacir Sant'Ana, “[...] o desenvolvimento comercial de Maceió, consequência do seu porto privilegiado, data de 1819" (SANTANA, 1970, p. 34), ano em que fezse estabelecer a Alfândega do Porto de Jaraguá. A então capital, Cidade de Alagoas (atual Marechal Deodoro), obteve esse status a partir de 1817, quando Alagoas se emancipou da Província de Pernambuco. Viveu um processo de decadência econômica e viu o seu porto marítimo, o do Francês, perder prestigio em virtude da ascensão do porto maceioense de Jaraguá. Além disto, não conseguiu desenvolver o comércio estrangeiro como pretendia a elite local, ao contrario de Maceió que, em consequência do bom funcionamento de seu porto marítimo, facilitou o estabelecimento de atividades mercantis, proporcionando desenvolvimento econômico para seus habitantes. (BARROS, 1991, p. 13).

Após uma tumultuada disputa envolvendo grupos políticos das duas cidades, ocorreu a transferência da capital alagoana, em 1839, para Maceió, a qual foi se consolidando como principal polo econômico-demográfico da região, sendo o local de residência de muitos senhores de engenho, comerciantes, autoridades e políticos, mas também de uma grande população de escravos, libertos, africanos livres e homens livres pobres. Até a década de 1830, a Vila de Maceió funcionava "[...] como um pequeno centro comercial para onde eram encaminhados o açúcar, o algodão, o fumo e a farinha de mandioca da zona interiorana da Província”. (GARDNER, 1975, p. 61).

A situação topográfica de Maceió e as possibilidades econômicas geradas pelo comércio marítimo em decorrência do Porto de Jaraguá4, que desde os anos 1830 se tornou o mais movimentado da Província, possibilitou torná-la o principal polo urbano das Alagoas oitocentista; (BARROS, 1991, P. 19), uma Província cuja economia estava baseada na monocultura açucareira e no trabalho escravo. Manuel Correia de Andrade analisou a relação da economia açucareira com a produção do espaço alagoano desde o século XVI, ressaltando o papel dos banguês do açúcar para o povoamento de Alagoas. (ANDRADE, 1997, p. 21-25).

A respeito da história do açúcar em Alagoas no século XIX, em que a presença da população cativa foi uma constante, ressaltou seu papel para a modernização das usinas e destilarias, (ANDRADE, 1997, p. 27) de modo que o fortalecimento do tráfico africano na região estava intimamente ligado à questão da cana-de-açúcar, Manuel Diégues Júnior documentou a presença do escravo negro na região, para ele: "[...] a manutenção do engenho reclamava grande escravatura”. (DIEGUES JUNIOR , 2002, p. 164). Portanto, inicialmente, foram os escravos que dinamizaram as relações produtivas. Abelardo Duarte sinalizou a existência de vários banguês e engenhos de açúcar próximos a Maceió; no ano de 1827 chegou-se a contabilizar trinta e quatro deles, um número que cresceu nas décadas posteriores. (DUARTE, 1980, p. 169-174). Devido à importância comercial que obteve ao longo do século XIX, as propriedades rurais: "[...] se transformaram em propriedades urbanas, cedendo os sítios lugar as construções das vias públicas e dos prédios marginais”. (COSTA, 2011, p. 20).

4 Segundo informações de Thomaz do Bom-Fim Espíndola, o Porto de Jaraguá foi fortificado em 1673 contra o ingresso de indígenas e estrangeiros contrabandistas de pau-brasil. (ESPÍNDOLA, 2001 [1871], p.136). 
Ao documentar o declínio da escravidão e a transição para o trabalho livre no Recôncavo Baiano, B. J. Barickman nos apresenta contrastes importantes na economia açucareira entre a Bahia e outras Províncias nordestinas, como Pernambuco e Alagoas, durante a segunda metade do século XIX. Apesar do fim do tráfico no pós-1850, que contribuiu para o declínio demográfico da população cativa do Brasil, na região Nordeste, a escassez da servidão se agravou por conta do tráfico interprovincial para as províncias do Sudeste onde a produção cafeeira se encontrava em pleno crescimento. Apesar destes fatores e das condições desaforáveis apresentadas pelo mercado mundial para a produção do açúcar:

[...] os senhores de engenho de Pernambuco e províncias vizinhas não só continuaram a cultivar a cana, como conseguiram aumentar sua produção. Tanto em Pernambuco como em Alagoas, as quatro décadas posteriores a 1850 viram um crescimento considerável no comércio exportador de açúcar. (BARICKMAN, 1998-99).

Diferentemente da Bahia, que sofreu uma estagnação e declínio na economia açucareira, tal conjuntura possibilitou à capital alagoana, Maceió, um desenvolvimento urbano e econômico, pois as exportações de açúcar no porto de Jaraguá atraiam comerciantes estrangeiros, e senhores de engenho vieram a fixar residência na cidade. Estudando a economia alagoana na primeira metade do século XIX, Moacir Sant'Ana informa que, desde a década de 1820, já havia a presença de negociantes ingleses em Maceió, pois ocorria uma intensa exportação de gêneros da produção local como o açúcar e o algodão para portos europeus. (SANT'ANA, 1970, p. 27).

Ao analisar o Relatório Provincial de Alagoas do ano de 1869, localizamos em anexo os Apontamentos sobre diversos assumptos geográficos-administrativos da Província de Alagoas, escrito por José Alexandrino Dias de Moura. Este documento - que descreve Maceió situada entre o oceano, ao leste, a lagoa, a oeste e ao norte, por uma cordilheira de outeiros expõe o desenvolvimento urbano da cidade entre as décadas de 1840 e 1860: "Maceió tem augmentado e progredido consideravelmente nestes últimos 20 annos e é hoje uma linda cidade ornada de bons prédios particulares e elegantes edifícios públicos" (sic.)5, como a Casa de Detenção, o Hospital da Caridade, o Palácio do Presidente da Província, a Assembleia Legislativa Provincial, a Câmara Municipal e o Mercado Público.

Segundo nos relata Moacir Sant’Ana, entre as décadas de 1840 e 1850, foram erguidas as igrejas: Nossa Senhora do Rosário, Nossa Senhora do Livramento, Nosso Senhor Bom Jesus dos Martírios e a Matriz de Nossa Senhora dos Prazeres. (SANT'ANA, 1966, p. 19-20). O viajante norte-americano Daniel Parish Kidder, descreveu a Maceió no inicio dos anos 1840:

\footnotetext{
5 MOURA, José Alexandrino Dias de. Apontamentos sobre diversos assumptos geográficos-administrativos da Província de Alagoas. Relatório lido perante a Assembléia Legislativa da Província de Alagoas no acto de sua instalação, em 16 de março de 1869 pelo presidente da mesma o Exm, Sr. Dr. José Bento da Cunha Figueiredo Júnior. Maceió: Typographia Commercial de A. J. da Costa, 1869.
} 
A cidade de Maceió se resumia em uma única rua. Ostentava duas igrejas em lamentável estado de conservação e, ainda assim, duas outras estavam em vias de construção; não havia, porém, convento algum. Os outros prédios públicos dignos de nota eram: o teatro, o palácio do governo, alojamentos para soldados e o Paço Municipal. [...] A despeito de vários motivos de interesse geral, o teatro estava inteiramente aberto, aparentemente abandonado e dando, um dos lados, a impressão de ter sido demolido para reforma ou caído em ruínas. Em grande parte, as casas de Maceió são construídas de taipa, e, com exceção de apenas uma ou duas, jamais excedem de um único pavimento. (KIDDER, 1980, p. 73).

O relato de Kidder sinaliza para o processo de urbanização de Maceió nos anos que se seguiam a 1839. As casas feitas de taipa com, no máximo, um pavimento eram comuns na cidade durante a primeira metade do século XIX, eram traços de uma vida rural que predominava na época, que, com a mudança da capital para Maceió, acabou por ocasionar uma reestruturação do espaço urbano.

Nesta época, a capital alagoana era dividida em duas freguesias: a de Jaraguá, onde fica localizado o porto marítimo, e onde eram situadas as ruas do Saraiva, da Alfândega, da Igreja, da Ponte, de Santo Amaro, da Matriz, do Amorin, do Cafunó, da Pajuçara, do Araçá, do Jasmim, do Goitizeiro, da Cacimba, do Bom Retiro e do Fogo. Na freguesia de Maceió ficava localizado o bairro de Maceió (cidade), atual região central da cidade, e as povoações ou arrabaldes (SANT'ANA, 1966, p. o9) que ficavam afastados do perímetro urbano: Trapiche da Barra, Poço, Bebedouro e Mangabeiras. No bairro de Maceió foram erguidos prédios públicos como a Câmara dos Deputados e o Palácio do Presidente da Província, e as principais ruas eram: Boa Vista, Sol, Rosário, Augusta, Alecrim e Boca de Maceió. Pelas informações de Tomaz Espíndola, as ruas do bairro da cidade eram “[...] pela maior parte paralelas à colina, todas sem calçamento, exceto a do Comércio [...], contendo todo o bairro 2.196 fogos, sendo 1.696 casas de telhas e 500 de palha”. Espíndola descreveu a povoação do Trapiche da Barra como um "[...] areal a mais de 5.00o jardas a oeste do porto de Jaraguá, à margem oriental da Lagoa do Norte [...]. Contém esta povoação uns 25 fogos, e uma capelinha de Nossa Senhora da Guia”. A região do Poço era situada entre a Freguesia de Maceió e de Jaraguá e possuía 200 fogos. Bebedouro, situado as margens da Lagoa do Norte ou Mundaú, tinha 150 fogos. (ESPINDOLA, 2001, p. 142). O mapa de Maceió na página a seguir é bem útil na localização dos bairros da cidade: 


\section{MAPA DA CIDADE DE MACEIÓ}

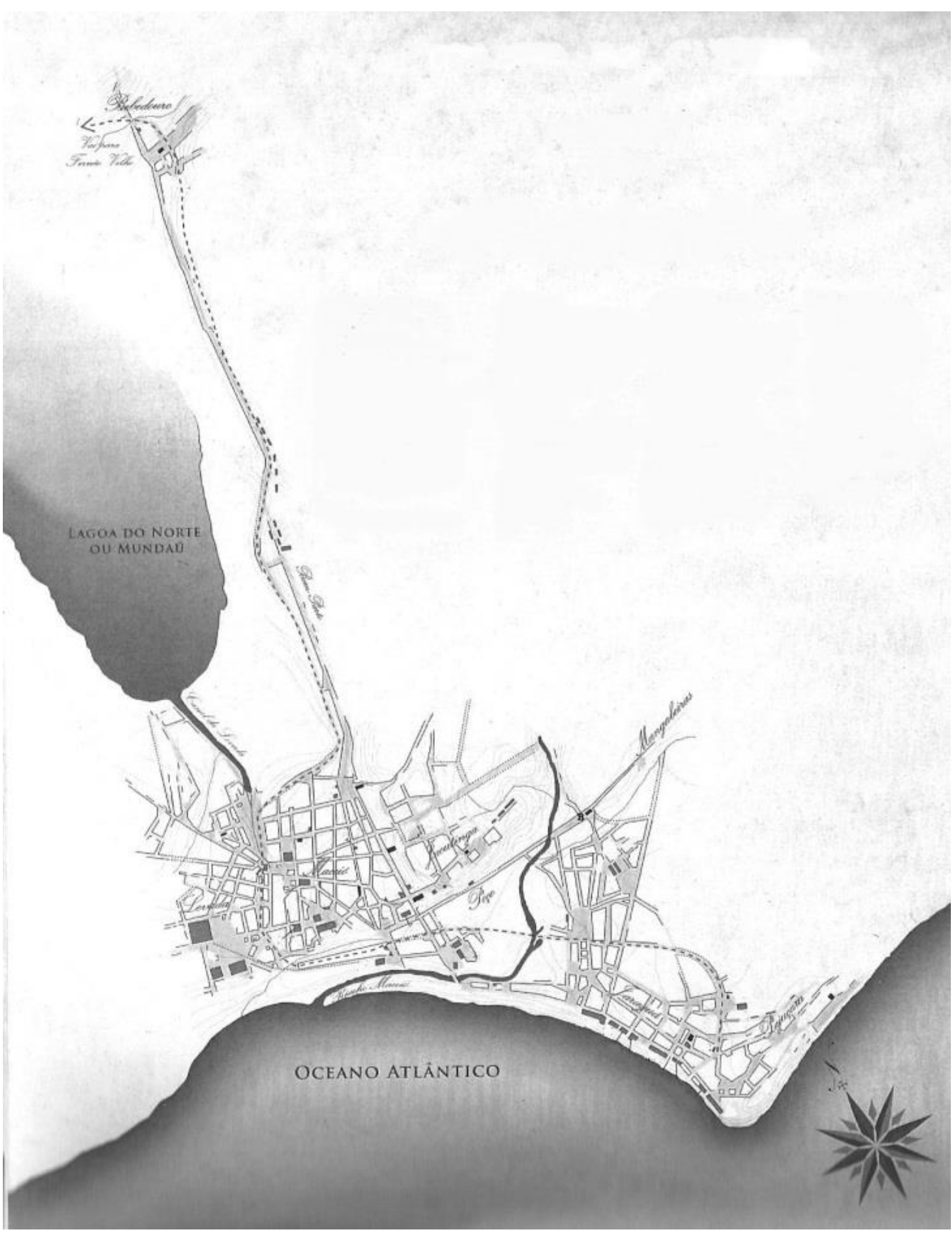


FORTES, Cynthia Nunes da Rocha. Maceió nos Itinerários de Pedro Nolasco Maciel. In: ALMEIDA, Luiz Sávio (org.) Traços e Troças: literatura e mudança social em Alagoas. Estudos em Homenagem a Pedro Nolasco Maciel. Maceió: Edufal, 2011, p. 132-138.

Na década de 1850, Maceió estava se consolidando como sítio urbano. Para Sávio de Almeida, a área urbana era apenas formada por Maceió e Jaraguá, sendo as regiões de Bebedouro, Trapiche da Barra, Mangabeiras e Poço consideradas como povoações: “[...]cuja vida estava associada à da cidade, sem a característica, ainda, de bairro, termo mais recente e que deriva da integração do território, cujo início efetivo é dado com os trilho urbanos”. (ALMEIDA, 2011, p. 90). Este autor também analisou os Apontamentos sobre diversos assumptos geográficos-administrativos, de Dias de Moura, e expôs que a região da Cidade (bairro de Maceió) se caracterizava como local de moradia da elite maceioense. Neste bairro a presença de escravos era maior, segundo Almeida: “[...] seria de esperar que a concentração de escravos estivesse onde se dava a maior concentração de renda: quanto maior a renda, maior o número de escravos." (ALMEIDA, 2011, p. 90). Também havia a presença dos africanos livres no bairro de Maceió. Nas regiões de Jaraguá, Poço, Trapiche da Barra, Mangabeiras, Bebedouro e seus entremeios, predominava a presença de escravos fugidos e homens livres pobres, buscando meios para sobreviver e resistir à hegemonia escravista.

O desenvolvimento urbano que perpassou a cidade de Maceió ao longo do século XIX, principalmente após 1839, quando foi elevada a capital da Província, foi acompanhado de um crescimento demográfico. Em 1847 a população maceioense contabilizava, segundo informações de Craveiro Costa, 16.064 pessoas, sendo 11. 902 livres e 4.162 escravos. Já no ano de 1855, dos 25.135 habitantes contabilizados, 6.230 eram escravos. Em 1870, a cidade de Maceió compreendia as freguesias de Maceió, Jaraguá e Pioca, “[...] com uma população de 28.630 indivíduos, em cujo número se contavam 4.822 escravos". (COSTA, 2011, p. 144 - 145). Ou seja, a população cativa era em média $25 \%$ entre as décadas de 1840 e 1850 , no ano 1870 caiu para 16\%. Em Recife, no ano de $1857,12,5 \%$ do total dos 64.840 habitantes dos bairros centrais da cidade eram cativos. (SOARES, 2011, p. 56). Já no Rio de Janeiro, em 1849, dos 205.906 habitantes da cidade $38,63 \%$ eram escravos, em 1872, 16,42\% dos 274.972 habitantes viviam sob o cativeiro. (SOARES, 2007, p. 34).

Após 1850, ocorreu uma diminuição da população cativa em Alagoas e em outras províncias nordestinas. Segundo o historiador Hélder de Melo: “[...] o período posterior à década de 1850, viu o número de escravos caírem significativamente, enquanto ocorria o movimento contrário em relação à população em geral”. (MELLO, 2011, p. 168). Além da proibição do tráfico atlântico e as mortes causadas por epidemias (EINSEBERG, 1977, p. 179), outro fator para tal acontecimento foi a exportação de escravos para o Sudeste, onde ocorria o desenvolvimento da economia cafeeira, "[...] a província de São Paulo absorveu grande parte dos escravos saídos de Alagoas”. (MELLO, 2011, p. 164). Maceió era o local que mais exportava escravos para o sudeste na década de 1850, como podemos observar na tabela abaixo:

\section{EXPORTAÇÃO DE ESCRAVOS NA PROVÍNCIA DAS ALAGOAS}




\begin{tabular}{|c|c|c|c|}
\hline LUGARES DE EXPORTAÇÃO & $1854 / 55$ & $1855 / 56$ & $\mathbf{1 8 5 6 / 5 7}$ \\
\hline CIDADE DE MACEIÓ & 155 & 136 & 367 \\
\hline CIDADE DE PENEDO & 85 & 73 & 229 \\
\hline VILLA DE SANTA LUZIA DO NORTE & 7 & $\mathrm{o}$ & 1 \\
\hline VILLA DE S. MIGUEL & 5 & $\mathrm{O}$ & 3 \\
\hline VILLA DE PÃO DE ASSUCAR & 3 & 5 & 15 \\
\hline VILLA DE PORTO DA FOLHA & 2 & 6 & 33 \\
\hline VILLA DE PORTO DAS PEDRAS & 0 & 1 & 11 \\
\hline VILLA DA MATA-GRANDE & 0 & 1 & 13 \\
\hline VILLA DA BARRA GRANDE & 0 & $\mathrm{o}$ & 10 \\
\hline VILLA DO PORTO-CALVO & 0 & 0 & 3 \\
\hline VILLA DO PAÇO DE CAMARAGIBE & 0 & 0 & 1 \\
\hline TOTAL & 257 & 222 & 686 \\
\hline
\end{tabular}

SANT'ANA, Moacir Medeiros de. Contribuição a História do Açúcar em Alagoas. Recife: Instituto do Açúcar e do Álcool e Museu do Açúcar, 1970, p. 147.

Se comparada à Cidade de Penedo, a segunda que mais comercializava escravos, Maceió se manteve, até 1857, com quase o dobro do número de escravos exportados, evidenciando, assim, uma grande importância na conjuntura econômica de Alagoas. A tabela a seguir, nos mostra o número de exportação de escravos em toda a Província:

EXPORTAÇÃO DE ESCRAVOS - ALAGOAS

\begin{tabular}{|c|c|c|c|}
\hline Anos & Quantidade & Anos & Quantidade \\
\hline $1852 / 53$ & 314 & $1857 / 58$ & 99 \\
\hline $1853 / 54$ & 116 & $1858 / 59$ & 77 \\
\hline $1854 / 55$ & 257 & $1859 / 60$ & 287 \\
\hline $1855 / 56$ & 222 & $1860 / 61$ & 157 \\
\hline $1856 / 57$ & 686 & $1861 / 62$ & 44 \\
\hline
\end{tabular}

SANT'ANA, Moacir Medeiros de. Contribuição a História do Açúcar em Alagoas. Recife: Instituto do Açúcar e do Álcool e Museu do Açúcar, 1970, p.147. 
Percebemos que, entre 1852 e 1862, foram exportados mais de dois mil escravos para as províncias do Sudeste. Tal situação ocasionou aumento da presença de homens livres pobres nos trabalhos de engenhos e fazendas alagoanas. Em Maceió, na Freguesia de Pioca, no ano de 1867, foram contabilizados 2.017 trabalhadores no setor da cana-de-açúcar, sendo 976 livres e 1.041 escravos. (SANT’ANA, 1970, p.150). Em alguns engenhos e fazendas, o número de homens livres pobres superou o de escravos. Juliana Alves de Andrade, apresentando os resultados parciais de seu projeto de doutorado intitulado Gente do Vale: trajetórias dos homens livres no Vale do Paraíba do Meio (Alagoas 1860-189o), sinaliza a forte presença do homem livre pobre do interior alagoano na capital em busca de meios para garantir sua sobrevivência. Historiando as formas de resistência dessa população, identificando as redes de sociabilidade e os modos de produção desses agentes, a historiadora expõe que eles eram, em sua maioria, negros libertos e ex-escravos. (ANDRADE, 2011, p. 189). Ao estudar tal questão em Pernambuco, Eisenberg expõe que muitos dos trabalhadores livres eram antigos escravos que permaneciam nas zonas açucareiras. (EISENBERG, 1977, p. 201).

O historiador Hélder Silva de Melo, analisando os dados estatísticos produzidos em Alagoas durante a segunda metade do século XIX, documenta uma diminuição do número de escravos em Maceió entre as décadas de 1850 e 1870, recorrendo aos dados de 1855/60 e 1872, quando registrou uma queda de 2.196 para 1.811 cativos. (MELO, 2011, p. 175). Outros motivos para a diminuição da população escrava em toda a Província de Alagoas foi a “[...] elevada mortalidade infantil entre os negros, mais a devastação causada pela varíola, febre amarela e principalmente pela cólera morbo, nos anos de 1855 e 1862". (SANT'ANA, 1970, p.145). A resistência escrava foi outro aspecto importante nesta conjuntura, conhecedores do que acontecia no Brasil oitocentista, referente às questões abolicionistas, muitos escravos fugiram ou procuraram obter a liberdade dentro das possibilidades que as leis ofereciam.

Durante os oitocentos, Maceió foi se estabelecendo como principal polo demográficoeconômico da Província de Alagoas e, em seu tecido social, notamos uma forte presença de escravos, libertos, africanos livres e homens livres pobres buscando seus meios de sobrevivência e resistindo à hegemonia escravista.

\section{Quotidiano e resistência: sociabilidade negra na Maceió do século XIX}

O romance Traços e Troças, do autor Pedro Nolasco Maciel'b, de fins da década de 1880 nos apresenta a história de amor entre um alfaiate, Manoel, e uma garota "pimenta e mal educada" de nome Zulmira. Ao longo da narrativa principal, apresenta indícios de como se configuravam os costumes e o cenário urbano de Maceió, nos trazendo uma visão panorâmica

\footnotetext{
${ }^{6}$ Pedro Nolasco Maciel (1861-1909) foi literato, tipógrafo e jornalista do Diário de Alagoas, um dos fundadores do jornal Gutemberg, de Maceió, e da Associação Tipográfica Alagoana de Socorros Mútuos. Além de redator em vários órgãos da imprensa maceioense como Tribuna do Povo, Orbe, Jornal de Notícias e O Popular. Também era abolicionista, foi um dos fundadores da Sociedade Libertadora Alagoana, em 1881, e da Sociedade Libertadora Artística, em 1884.
} 
da cidade de fins do século XIX e, em algumas passagens, nos remete à presença africana no quotidiano da capital alagoana. Como a história do africano Félix, acusado de praticar feitiçaria:

Lera nos jornais que dois carteiros do correio Luiz Cunha e Anastácio Costa, ambos jovens vendendo saúde, morreram de febres palustres em poucos dias, porque abriram um pacote de feitiço vindo do Rio para o africano Félix da Costa, em Jaraguá, que outro empregado estava enfermo: que o prelo do jornal que dera notícia, chamando a atenção da polícia, quebrara-se: que o Braz, subdelegado, teve receio de prender o negro feiticeiro. (MACIEL, 1964, p. 147).

Havia na cidade inúmeros terreiros de xangô, pequenos quilombos ao redor e intensa movimentação de escravos, libertos, africanos livres e homens livres pobres nas ruas em busca de seus meios de subsistências, sendo comum encontrá-los em rodas de capoeiras e manifestações culturais como: o coco de roda, nas músicas de barbeiros e no lundu. Em seu romance, Pedro Nolasco Maciel se refere a personagens como Adolpho, "africano velho do Jaraguá”; Geroncio, “creoulo canoeiro" e a "preta” Maria Benta, quituteira. Além de mencionar os batuques do maracatu em meio às ruas da cidade e a existência da irmandade do Rosário.

A historiografia brasileira vem se dedicando com maior fôlego ao estudo da escravidão e da presença africana nas cidades durante o século XIX, contribuindo para o preenchimento de importantes lacunas na história da escravidão, e atentando para as particularidades das vivências urbanas. Enidelce Bertin, estudando a São Paulo do século XIX, afirma que a escravidão urbana configurou-se pelo trabalho de ganho e aluguel, a mobilidade física dos escravos e por relações paternalistas. (BERTIN, 2006, p. 57). A cidade era um centro para onde confluíam homens livres, escravos e libertos em busca de serviços de ganho no comércio, ou fugidos das fazendas em busca de esconderijos. Bertin expõe que “[...] no cenário de um centro urbano em constante contato com os arredores, a escravidão garantia intensa a movimentação humana que as atividades urbanas demandavam”. (BERTIN, 2006, p. 46).

A escravidão nas cidades brasileiras proporcionou aos escravos múltiplas ocupações e o desempenho de quase todas as funções da economia citadina, tais como a de carregadores, trabalhadores nos portos, oficinas, lavadeiras, quitandeiras, domésticas, artesãos. (WISSENBACH, 1998, p. 63). Na capital alagoana, sinaliza Alfredo Brandão, os escravos estavam inseridos "[...] ora nos trabalhos domésticos, ora como pedreiro a construir casas, ora como ferreiro a forjar machados e foices, ora como sapateiro a fazer sandálias”. (BRANDÃO, 1988, p. 41). Para os cativos: "[...] se o senhor é comerciante, ele é carregado dos serviços pesados - transportar os fardos as costas, conduzir as carroças, varrer as lojas, limpa os balcões”. (BRANDÃO, 1988, p. 41). O historiador Felix Lima Júnior apontou que os negros, em Maceió, trabalhavam como canoeiros, copeiros, vendedores de frutas e de aves, pães, peixes e doces, cozinheiros, como serventes e no transporte de 'tigres' (barris de madeira que serviam para o transporte de excrementos). (LIMA JR., 1983, p. 95). No cenário urbano, os cativos transitavam com extrema agilidade pelas ruas da cidade e desenvolveram sociabilidades que 
proporcionavam a busca pela sobrevivência assim como oportunidades de resistência. Para Wissenbach:

No dia-a-dia, os escravos e libertos tiveram de se defrontar com os encargos do sobreviver, com as exigências impostas pelo viver citadino e improvisar respostas compatíveis à resistência contra a escravidão. Transformaram as vicissitudes da discriminação, da escassez de recursos e da ausência de instituições que lhe assistissem, num duro aprendizado da experiência de liberdade. (WISSENBACH, 1998, p. $15)$.

Portanto, cotidianamente, a população negra buscou, ou teve que afirmar, a emancipação, o que torna importante compreender como os escravos e os africanos livres "[...] desenvolveram a autonomia e a resistência segundo as condições colocadas pelo viver na cidade”. (WISSENBACH, 1998, p. 42). No caso desta pesquisa, a vivência negra na Maceió do século XIX, uma cidade que estava se afirmando como sítio urbano. (ALMEIDA, 2011, p. 89). O viajante norte-americano Daniel Kidder, relatou em sua passagem pela capital alagoana no ano de 1842 aspectos do dia-a-dia da cidade, como por exemplo, a presença africana nas ruas:

Não se constituía espetáculo lá muito edificante os grupos de crianças completamente nuas, pelas ruas, mesmo assim não pudemos deixar de nos divertir com um negrinho que corria de um lado para o outro, orgulhoso de seu par de sapatos, a única peça de vestimenta - se assim se pode dizer - que tinha no corpo. Todavia, os sapatos constituíam sinal de alforria e por isso, tanto o garoto como seus pais, tinham, sem dúvida, motivo para se sentirem orgulhosos. (KIDDER, 1980. P. 74).

O trecho acima sinaliza para a dura luta em busca de liberdade que os escravos travavam diariamente contra a hegemonia senhorial, ao calçar os sapatos, o "negrinho nu" que corria estava se afirmando como livre. Segundo Robert Conrad, “[...] era negado o direito ao uso de calçados ou qualquer proteção para os pés, porque pés descalços simbolizavam a condição de escravo". (CONRAD, 1985, p. 27). Desta forma, logo que um escravo obtivera sua alforria procurava afirmar sua nova condição calçando sapatos, (CUNHA, 1988, p. 23) era uma atitude de afirmação social. Os relatos de viajantes estrangeiros possibilitam o vislumbre do cotidiano da população cativa e o ambiente em que viviam, Kidder, em meio ao seu modo de ver característico dos viajantes do século XIX, sinalizou fragmentos dos modos de ser da população escrava e liberta da capital alagoana. Seu relato, se analisado a contrapelo, se torna uma importante fonte para vislumbrar o quotidiano da escravidão em Maceió.

$\mathrm{O}$ viajante norte-americano também descreve a presença de homens e mulheres de "tez escura" em frente a uma cabana no bairro de Jaraguá, os escravos que carregavam potes de água na cabeça e uma cena na praia, em casa de um português, esperando "[...] um negro que devia subir ao coqueiro e apanhar os cocos". (KIDDER, 1980, p.80.). O que é elucidativo das 
ocupações citadinas dos escravos, o negro desenvolvia serviços para suprir suas necessidades de subsistência.

Uma passagem interessante no relato de Kidder é a descrição de um "negro velho" pedindo esmola, o que nos remete a pensar a situação social da população cativa e liberta quando atingiam uma idade avançada:

Ao pé da santa estava um negro velho com um xale sobre os ombros e uma bandeja na mão. Perguntando-lhe o que tinha naquele escrínio, respondeu ele: 'Nossa Senhora do Rosário'. - O que está fazendo ela? - Pedindo esmola para a construção de uma igreja. (KIDDER, 1980, p.74)

Outro viajante que esteve em Maceió foi o botânico britânico George Gardner, o qual relatou que a cidade ficava "[...] numa elevação plana de cinquenta ou sessenta metros acima do nível do mar e dele dista cerca de um quarto de milha”. (GARDNER, 1975, p. 61). Por ser botânico, o relato de Gardner foca muito nas descrições geográficas, mesmo assim, nos fala de seu "empregado preto" que fazia seus serviços e o acompanhava nas viagens a outros lugares da Província como o Rio São Francisco, ao sul de Alagoas. O qual também foi destino do viajante alemão Robert Ave-Lallement, no ano de 1859, quando esteve em Maceió, ocasião em que ao deixar a capital em direção ao sul da Província embarcara "[...] numa pequena canoa, sua tripulação, apenas um negro velho. Este cuja cabeça branca contrastava singularmente com a cara preta”. (AVÉ-LALLEMENT, 1980, p. 280). Evidenciando a presença do negro canoeiro no quotidiano de Maceió, destacava a cidade banhada pelo mar e pelo complexo lagunar mundaúmanguaba. Em cidades do litoral nordestino como Recife e Maceió, um importante ofício era o do canoeiro. Ao estudar a capital pernambucana, o historiador Marcus de Carvalho se refere ao fornecimento de água, que dependia de escravos e negros canoeiros, uma profissão bastante procurada pela população cativa. (CARVALHO, 2001, p. 30-31).

Luís Sávio de Almeida, no seu livro sobre a Cabanada, (ALMEIDA, 2008) faz uma análise da história alagoana da primeira metade do século XIX e expõe que Maceió foi uma cidade que surgiu à sombra do Quilombo dos Palmares, o qual abrangia boa parte do território alagoano ao longo do século XVII. (DIÉGUES JUNIOR, 2002, p. 169). Para tal questão, resgata as abordagens de Clovis Moura sobre a "síndrome do medo" instalada na sociedade escravista, articulada aos "temores pânicos", expressão cunhada pelo Governador da Província de Pernambuco alusiva ao momento que antecedeu ao episódio dos malês em Salvador, no ano de 1817.

A síndrome do medo engendrou os temores em Alagoas, houve rumores de uma rebelião escrava, em 1815, em Penedo e na cidade das Alagoas. (ALMEIDA, 2008, p. 39). Nesta perspectiva, acreditamos que é de fundamental importância para a compreensão da dinâmica social da Maceió do século XIX, situá-la nesta conjuntura.

No ano de 1829, ocorreram dois focos de "ajuntamento" de negros na Massagueira. Em 1830, houve a descoberta de um quilombo no Trapiche, e pediu-se uma tropa ao Juiz de Paz da 
Vila de Maceió para atacar os quilombolas. (ALMEIDA, 2008, p. 56). No século XIX, era comum a existência de quilombos nos arredores de cidades como São Paulo e Recife. Segundo Manoel Diégues Junior, no decorrer dos oitocentos, constituíram-se vários pequenos quilombos nos arredores da Cidade de Alagoas e Maceió, onde os "pretos viviam assaltando a quem passava e aos diversos engenhos das redondezas". (DIÉGUES JUNIOR, 2002, p. 175). Esse historiador cita uma notícia do jornal Diário das Alagoas do ano de 1861 se referindo à prisão do "calhambola” José Rosa, chefe do quilombo da Mata do Rolo. (DIÉGUES JUNIOR, 2002, p. 175). Em pesquisa realizada por nós na Biblioteca Nacional, no fundo Arthur Ramos, localizamos uma matéria do referido jornal sobre tal quilombo:

Cada dia chegam-nos noticias de novos atentados perpretados pelos calhambolas amocambados na Matta do Rolo e Taboleiro do Pinto, onde dizem que há quem proteja ou auxilie esses acelerados. Já pedimos a attenção as autoridades superiores sobre a extinção desse quilombo; e de novo imploramos providências para a segurança da vida e propriedade dos que vêem-se forçados a transitar por aqueles lugares e dos moradores circuvisinhos (sic.). ${ }^{7}$

Acompanhando o editorial deste jornal, o qual foi definido pelo historiador Abelardo Duarte como "conservador e intransigente" (DUARTE, 1988, p. 51), notamos uma forte relação com os interesses da classe senhorial, neste exemplo acima citado, devemos levar em consideração que foi uma forma dos senhores de engenhos cobrarem das autoridades a extinção do quilombo visando à defesa de suas propriedades. O Diário das Alagoas $^{8}$ publicava outros anúncios de fugas de escravos e notícias sobre possíveis crimes cometidos pela população cativa e as medidas tomadas pelas autoridades visando o controle social, como a matéria abaixo:

Em conseqüência da perseguição que tem feito a policia aos escravos fugidos, foi preso hontem e acha-se recolhido á cadeia desta cidade o preto Roque, e dispersaram-se dous de seus principais companheiros que compunham o grupo que assassinou o infeliz Plates, único que foi victima do mesmo grupo. A policia continua a empregar todos os meios ao seu alcance para descobrir os diversos ranchos onde existem outros, e neste sentido tem expedido as mais terminantes ordens (sic.)9.

Uma análise nas entrelinhas das matérias deste jornal permite-nos vislumbrar o quotidiano da Maceió do século XIX no que tange as tensões sociais inerentes ao período após a promulgação da lei Eusébio de Queiroz. Além dos quilombos que existiam nos arredores da cidade, outro reduto de escravos fugidos localizava-se nas regiões da Levada e do Trapiche da Barra. No romance de Pedro Nolasco Maciel, encontramos uma passagem que nos fala do perigo

7 IHGAL. Diário das Alagoas, Boletim Quilombo.11/11/1861.

8 É interessante saber que este jornal foi criado em 1858, segundo Moacir Sant'Ana, tendo sido o primeiro da Província de Alagoas a ter publicação diariamente e, portanto, tinha grande circulação na sociedade e estava inserido nas relações de poder do sistema escravista, em um momento pós-Lei Eusébio de Queiroz.

9 IHGAL. Diário das Alagoas. 13/11/1861. 
em transitar por uma estrada localizada nestes locais em virtude da existência "[...] de muitos ladrões em sua maioria parte de soldados desertores e escravos fugidos". (MACIEL, 1964, p. 57).

Felix Lima Júnior documentou que havia negros escondidos nos “[...] brejos e entre os cajueiros, murtas, ouricuris e outras árvores no areal entre o centro da cidade, capital da Província, e o ponto de desembarque dos que vinham do Pilar e de Alagoas". (LIMA JUNIOR, 1975, p. 54). A população escrava desenvolvia artimanhas e necessitava de segredos, esconderijos e quilombos, para se camuflar e resistir ao controle senhorial. (ALMEIDA, 2008, p. 181). Sidney Chaloub, estudando as últimas décadas da escravidão no Rio de Janeiro, descreveu cenas de uma cidade negra, alternativa e arredia, instituída por escravos, libertos e negros livres pobres que desafiavam a instituição da escravidão. (CHALOUB, 1990, p. 28). A população cativa se mostrava incansável em seu objetivo de "[...] transformar a cidade num esconderijo. A cidade que esconde é, ao mesmo tempo, a cidade que liberta”. (CHALOUB, 1990, p. 219). Tal questão é elucidativa de como os negros ocuparam os espaços da capital alagoana com a perspectiva de atingir a liberdade.

Os anúncios de fugas de escravos era uma constante nos jornais alagoanos, não apenas no Diário das Alagoas, mas em outros como o Progressista. Moacir Sant'Ana expõe que as autoridades utilizavam de vários artifícios para reduzir o número de fugas, uma delas foi o toque de recolher após as nove horas da noite. Os escravos que fossem encontrados na rua após o horário estipulado "[...] sem escrito do senhor datado do mesmo dia, na qual declare o fim a que vai, será recolhido à prisão e multado o senhor em 3 \$ooo”. (SANT’NA, 1966, p.31). A presença de escravos nas ruas no período noturno era uma constante nas cidades brasileiras no século XIX. Alusivo à Maceió, encontramos um documento na Biblioteca Nacional pedindo providências a respeito dos "[...] pretos e capoeiras que depois do anoitecer forem encontrados com armas ou em desordem", citado a seguir:

Tendo fallecido hoje o negociante desta praça, Joaquim Antonio Alves, em conseqüência de uma facada que recebera hontem ao anoitecer, dada, segundo elle mesmo o dissera, por um preto que fingira atrapalhar-se com o assassinado, a Regência em nome do Imperador o Senhor Dom Pedro II, manda recomendar a Vm a expedição das mais terminadas ordens, para que desde o anoitecer sejão apalpados os pretos com o maior escrúpulo e castigados devidamente todos os que forem achados em desordem. O Governo espera que Vm dará sobre este objeto as mais eficazes providencias, a fim de prevenir-se a reicindencia de taes acontecimentos $(\text { sic. })^{10}$.

Datado de 1834, este documento foi escrito pelo Juiz de Direito Chefe de Polícia Aureliano de Souza e Oliveira Coutinho, e nos permite captar as evidências de comportamento da população cativa no período noturno nas ruas de Maceió. Formara-se, na cidade, um tempo e espaço de resistência às regras impostas pelas autoridades para o controle social. Reuniões noturnas de escravos praticando capoeira causaram temores às autoridades, que reagiram

${ }^{10} \mathrm{BN}$. Dá providencias a respeito dos pretos e capoeiras, que depois do anoitecer forem encontrados com armas ou em desordens.I-36,25,034. 17/04/1834. 
através da repressão e controle dos movimentos dos escravos no tempo e espaço. (SOARES, 2002).

Os jornais do século XIX, apesar de possuírem um teor criminalizante sobre a população cativa, se analisados a contrapelo, tornam-se uma importante fonte para captar as nuanças de comportamento inerentes ao quotidiano de uma sociedade escravista. No caso de Maceió, o historiador Felix Lima Júnior listou alguns jornais que circulavam pela capital alagoana ao longo das décadas do século XIX, em seu capítulo intitulado Escravos Fugidos do livro A Escravidão em Alagoas (LIMA JUNIOR, 1975), cita-nos alguns casos como o da africana de nome Antonia da Costa, publicada no jornal O Tempo, em 24 de outubro de 1857:

Fugiu da abaixo assinada uma escrava de nome Antonia da Costa, alta, corpulenta, bem preta, tem falta de um dente na parte superior, numas das pernas uma cicatriz proveniente de uma goma, na mão direita tem um dedo aleijado, anda constantemente de chinelos, tem bastante cravos nos pés e já não é muito moça; há noticias que anda lá para as bandas da Pedra de Fogo; quem a apreender será bem gratificado. (LIMA JUNIOR, 1975, p. 49-50).

Este anúncio traz informações significativas sobre a idade e o estado de saúde da escrava Antonia. A falta do dente, a cicatriz na perna e o dedo aleijado na mão direita parecem indicar que tais sequelas foram frutos dos maus tratos de sua senhora ou das condições de trabalho que proporcionava. No anúncio, observamos a informação de que a escrava já não era muito moça, talvez não suportasse mais o dia-a-dia da escravidão e resolvera praticar a fuga. $\mathrm{O}$ mesmo jornal publicou também a fuga de uma escrava chamada Rufina, de 18 anos: "Fugiu no dia 11 do corrente uma escrava creoula por nome Rufina, idade 18 anos, altura regular, tem falta de um dente na frente, bem esperta, levou saia de chita amarela"11. Tais anúncios nos apontam para um quotidiano de luta e resistência das mulheres negras na Maceió oitocentista.

Ao estudar as músicas de barbeiros na cidade de Maceió, Abelardo Duarte cita uma passagem do livro de Manuel Diégues Júnior referente a um escravo do Doutor Antônio Bahia da Cunha que se encontrava fugido, e que sempre estava presente nas reuniões de bandas musicais dos negros tocando flautins e clarineta. (DUARTE, 2010, p. 129). O jornal Diário do Comércio publicara, em 16 de abril de 1862, um anúncio sobre tal escravo:

Fugiu da casa do Sr. Dr. José Antônio Bahia Cunha o seu escravo de nome Silvério, creoulo, estatura regular, representando ter a idade de 25 a 30 anos, cosinheiro, é acostumado a tocar nas músicas de barbeiro flautim e clarineta. Quem dele der notícias ou levá-lo à casa de seu senhor, na rua Boa Vista, será gratificado (sic.) ${ }^{12}$.

A historiadora Maria de Fátima Novaes Pires, ao estudar a escravidão no alto sertão baiano, analisou os encontros festivos onde os escravos, forros e ex-escravos ocupavam os

\footnotetext{
${ }^{11}$ IHGAL. O Tempo. 16/07/1857.

${ }^{12}$ IHGAL. O Diário do Comércio. 16/04/1862.
} 
espaços das pequenas vilas, cidades, roças e arrabaldes: e "[...] transgrediam os limites de escravizados e criavam espaços de liberdade em encontros festivos e improvisadas diversões cotidianas". (PIRES, 2009, p. 242). O historiador Eduardo Silva sinalizou as "fugas para dentro", onde os escravos se ocultavam na própria cidade, se utilizando do espaço como tática de resistência. (REIS, 1999, p. 71-72).

Na cidade de Maceió, ao longo do século XIX, existia a presença dos africanos livres. Recentemente, a historiografia da escravidão no Brasil tem voltado seus olhares sobre eles, tirando do silêncio as desconhecidas experiências de vida desta população que não era considerada escrava, entretanto, viveu em estreita relação com a escravidão. Ficaram conhecidos como os "meia-cara", pois, não eram escravos e nem libertos, tendo que se afirmar no quotidiano como livres. (BERTIN, 2006).

Uma análise feita sobre a documentação da Curadoria dos Africanos Livres de Alagoas, localizada no Arquivo Público do Estado de Alagoas, nos permitiu perceber a forte presença desta categoria no quotidiano da Maceió do século XIX, sendo de grande valia sua análise para melhor compreender a sociabilidade negra na cidade. Segundo Abelardo Duarte, a curadoria expediu e recebeu ofícios e demais papéis sobre esta população durante trinta anos, de 1836 a 1866. (DUARTE, 1988, p. 63). Esta documentação nos permite detectar aspectos da vida cotidiana desta população como a formação de famílias, trabalho, resistência e transgressões. Para Moises Sebastião Silva, esta documentação consiste em: “[...] correspondências do curador dos africanos livres com os presidentes da Província, requerimentos de administradores de estabelecimentos públicos, de arrematantes particulares" (SILVA, 2011, p. 27) e dos africanos, no caso destes últimos solicitados por meio de procuradores.

A documentação acima citada refere-se aos africanos livres que foram apreendidos em desembarques clandestinos entre as décadas de 1840 e 1850 nas praias do litoral norte de Alagoas, com destaque para a região dos morros de Camaragibe, local onde o desembarque ilegal de africanos era uma constante. Após serem levados para a capital alagoana, Maceió, tinham dois destinos: prestação de serviços a particulares ou trabalhar em obras e instituições públicas. No primeiro, teriam seus serviços arrematados por pessoas como doutores, militares, padres, funcionários públicos e políticos. No segundo, eram destinados a trabalhar em locais como: o hospital de caridade, hospital militar, cadeia, secretaria do Palácio do Governo e em obras publicas, como a construção do Farol de Maceió. (SILVA, 2011, p. 30). A maioria dos africanos livres eram arrematados por particulares e: "[...] foram postos nos serviços domésticos, no campo, ao ganho nas ruas e alugados a outros particulares. Nos estabelecimentos públicos trabalhavam na limpeza, lavagem de roupa, na cozinha, etc.” (SILVA, 2011, p. 31)

Robert Conrad expôs que, em geral, os africanos livres eram destinados ao serviço agrícola nas áreas rurais, e nas cidades “[...] utilizados como pretos de ganho, negros mandados por seus proprietários (neste caso, por seus tutores), para oferecerem seus serviços ao público, ou venderem mercadoria nas ruas". (CONRAD, 1985, p. 174). Os que eram mantidos sob o 
controle do governo eram destinados a ocupações urbanas. Conrad cita um grupo de africanos livres que foi designado a trabalhar em repartições públicas como na "iluminação das ruas do Rio de Janeiro, delegacia de polícia e serviço de abastecimento de águas”. (CONRAD, 1985, p. 174). Enidelce Bertin documentou que os africanos livres, nos serviços públicos, trabalharam como: calceteiros, pedreiros, ferreiros, roceiros, cozinheiros, faxineiros, lavadeiras, cuidadores de doentes, transportadores de água e de alimentos, compras, serviços de jardinagem, em limpeza de córregos e vias publicas, nos serviços de enxada e na quebra de pedras de calçamento.”. (CONRAD, 1985, p. 174).

Entre os papéis avulsos da Curadoria dos Africanos Livres de Alagoas, nos deparamos com o pedido de emancipação de Faiel, o qual:

[...] sendo apprehendido como contrabando no anno de 1850 foi desde então applicado para prestar seus serviços na Cadeia d' esta Cidade, onde se conservou por algum tempo, até que mostrando alli hum menos reprehensivel comportamento, passou a prestar os mesmos serviços no estabelicimento publico do Collegio dos Educandos artifices, onde se tem conservado até o prezente com melhor conducta, segundo me informou o actual Director do referido collegio. Hé quanto m' occorre d' informar a V. E. a respeito do seo africano livre (sic.) $)^{13}$.

A Cadeia de Maceió e o Colégio dos Educandos foram duas instituições públicas que tiveram africanos livres prestando serviços, todavia, esses africanos demonstravam constantemente "menos boa conducta" (sic.) ${ }^{14}$. Era a maneira de se afirmarem como cidadãos livres. Outra instituição pública que recebia os serviços da população dos africanos livres fora o Farol do porto da cidade de Maceió, no qual trabalhou africano livre Miguel:

[...] este foi com outros apprehendido em janeiro do anno de 1850, como contrabando, nas praias dos morros de Camaragibe desta Província, e desde logo em Março do seo anno forão seus serviços arrematados pelo Tenente Coronel Francisco de Meira Lima, donde por permissão d[e?] V. E. passara para o serviço do pharol, onde prezentemente s' acha, em substituiçam a outro de nome Braz, que mal servia, e com desagrado do actual Administrador (sic.) ${ }^{15}$.

Miguel requereu sua emancipação no ano de 1861, alegava o seu procurador João dos Santos Lima, o africano:

[...] não tem desde que chegou no Brasil [...] gosado das vantagens de sua liberdade, [...] que já tendo decorrido dose annos desse captiveiro, mande V.aEx.cia dar liberdade ao supplicante para que passa ganhar os meios com que possa viver (sic. $)^{16}$.

\footnotetext{
${ }_{13}$ APA. Informação sobre req. Faiel env. pelo Curador ao Pres. Prov. 15/04/1861.

${ }_{14}$ APA. Informação sobre req. Bernardo e Faiel env. pelo Curador ao Pres. Prov. 12/04/1861.

${ }_{15}$ APA. Informação sobre req. Miguel env. pelo Curador ao Pres. Prov. 19/02/1861.

${ }^{16}$ APA. Requerimento de Carta de Emancipação - Miguel. 15/02/1861.
} 
Após a emancipação de Miguel, o administrador do Farol do porto, o senhor Henrique d' Azevedo Melo solicitou à Curadoria outro africano livre para prestar serviços no dito local, para onde foi designado o africano de nome Benedito, todavia, ele era acusado de ser "[...] mui relaxado, insubordinado, e calaceiro" (sic.)17, além de "há dias que desappareceo desta Cidade, e anda fogitivo, sem delle haver noticias" (sic.) ${ }^{18}$. O documento citado nos traz indícios de como era a vida quotidiana nesse local, além de nos evidenciar que o administrador, o senhor Henrique d'Azevedo Melo, utilizava-se dos africanos livres para servi-lo particularmente, ele pediu: “[...] a concessão d' hum africano livre, que lhe conduza agua ao lugar de sua residencia no alto, em que s' acha collocado o seo pharol" (sic.) ${ }^{19}$. Tal fato reforça a ideia de que a categoria dos africanos livres foi uma maneira encontrada pelas autoridades para a manutenção da escravidão e da hegemonia senhorial, como assinalou Enidelce Bertin. (BERTIN, 2006).

Em sua grande maioria, os africanos livres eram arrematados por particulares. Ao elaborar uma estatística dos africanos livres referente ao ano de 1850, Moisés Sebastião aponta que de 66 africanos, 58 foram destinados a prestar seus serviços a particulares. (SILVA, 2011, p. 34). Foi o caso do africano livre Adriano, arrematado por Felisberto Peixoto de Araujo Lima:

Felisberto Peixoto de Araujo Lima, pedio e tomou conta do Africano Adriano e de sua competente carta de liberdade com que se achão as declarações seguintes - Numero seis - Adriano - nação Nagôu quinse annos - rosto comprido - olhos, nariz, beiços e orelhas regulares - tendo no peito direito - $\mathrm{Y}$ - e onze sicatrizes em cada face; - obrigou-o a fazer batizar quanto antes, conservando o nome de Adriano, a dar conta da sua carta de liberdade, e a pagar annualmente [fl.1v] quinse mil reis, a apresental-o ao Curador sempre que este o deva visitar, kasal-o com toda humanidade, entregar quando falte a alguma das condições, ou o Governo o exija (sic.) ${ }^{20}$.

Africanas livres arrematadas por particulares eram uma constante na documentação mencionada. Foram, geralmente, destinadas aos serviços domésticos, a exemplo de Henriqueta, arrematada por Manoel Carneiro d' Almeida e, após seu falecimento, ficara em poder da viúva ${ }^{21}$. Outro exemplo é o da africana livre Francisca, arrematada no ano de 1850 por Joaquim Jozé d' Almeida, e que morava com suas duas filhas na casa do arrematante, como podemos perceber na documentação: “[...] tem ella produzido duas crias que existem em companhia da mesma africana, em poder do arrematante de seus serviços” (sic.)22. Outro caso interessante foi o da africana livre Izabel, arrematada pelo senhor Antonio d' Almeida Franco no ano de 1850:

[...] tendo ella por algum tempo / talvez mais d' 8 annos / prestado seos serviços, fora abandonada por aquel[le] arrematante, que

\footnotetext{
${ }_{17}^{17}$ APA. Informação sobre req. Henrique d' Azevedo env. pelo Curador ao Pres. Prov. 05/04/1861.

18 Idem.

19 Idem.

20 APA. Cópia do Termo de Arrematação do af. Adriano. 17/05/1861.

${ }^{21}$ APA. Informação sobre req. Andre, Manoel e Henriqueta env. pelo Curador ao Pres. Prov. 29/04/1861.

22 APA. Informação sobre req. Francisca env. pelo Curador ao Pres. Prov. 04/06/1861.
} 
mudando de [re]zidencia para fora da Província, a deixara nesta Cidade entregue a preta liberta de nome Ritta em Jaraguá, por que ou não obtivera permissão da Prezidência, ou por que não teve meios de pagar os sallarios d' alguns annos deccorridos, à que era obrigado, e se sujeitara no termo da pr[corroído] arremataçam (sic. ${ }^{23}$.

Tais circunstâncias nos remetem a pensar como se configurou a sobrevivência cotidiana de Izabel. Abandonada pelo arrematante, teve que lutar diariamente para conseguir pecúlios e buscar sua emancipação. No dia-a-dia da trama social da escravidão: escravas, libertas e africanas livres tiveram que buscar, cotidianamente, meios de sobrevivência e resistência, fosse comercializando produtos nas ruas, pedindo esmolas ou trabalhando em serviços domésticos. A Maceió dos oitocentos foi marcada pela intensa movimentação da população negra na cidade, destacamos a presença escrava e dos africanos livres que ocuparam as ruas, praças, becos e locais desertos dos arredores da capital alagoana para resistir à escravidão, mas também para buscar seus meios para garantir-lhes a sobrevivência. Desta maneira, construíram amizades, fizeram parceiros, foram solidários e também cometeram crimes. (BERTIN, 2006, p. 122). Nas páginas a seguir trataremos do quotidiano das mulheres negras e como elas desenvolveram seus arranjos de sobrevivência e resistiram à hegemonia escravista.

\section{Vendendo doces e engomando pro senhor: o comércio nas ruas e os serviços domésticos de escravas e africanas livres}

Abelardo Duarte, ao pesquisar o folclore negro nas Alagoas, registrou as poesias do cantador negro Joaquim Puerame, arrolados por Theo Brandão e Aloisio Vilela ${ }^{24}$ no inicio do século $\mathrm{XX}$, apresentando uma poesia alusiva às negras quitandeiras e vendedoras de tabuleiro de doces em Maceió:
A nêga veia ta vendendo doce
Lá no hoté
Nêga da costa lá de Maceió
Ela levanta o bendegó,
E vai prá o hoté,
Ela vende cardo de cana
Vende caju, banana,
E o sarapaté,
Ela vende a bolacha simpatia,
E também vende a bolacha soe,
E ela diz quando o matuto passa,
Ô meu sinhô venha toma café,
Repara Zé,
Que a Nega ta vendendo doce.
Lá no hoté. (DUARTE, 2010, P. 159).

Tal poesia nos apresenta uma das facetas cotidianas de escravas e africanas livres na Maceió do século XIX. Outra foi apontada pelo poeta alagoano Jorge de Lima (1893-1953), o

\footnotetext{
${ }^{23}$ APA. Informação sobre req. Izabel env. pelo Curador ao Pres. Prov. 20/05/1861.

24 Pesquisadores do folclore alagoano pertencentes a chamada Escola de Maceió.
} 
qual tem uma obra diversificada e, a partir dos anos vinte publicou uma série de poemas fundamentados em um forte sentimento nacionalista. Também exaltou o folclore negro, culminando com a publicação de seus Poemas Negros em 1947. (CAVALCANTE, 2005, p. 8285). Mas vinte anos antes, em 1927, no seu livro Novos Poemas nos apresentou uma tal Negra Fulô e seus serviços domésticos:

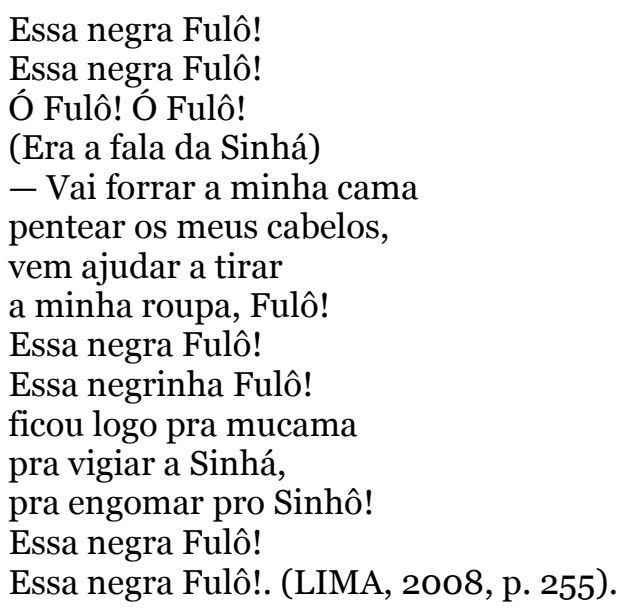

As duas poesias são elucidativas quanto ao quotidiano das mulheres negras na Maceió e em outras cidades brasileiras do século XIX, as quais tinham que desenvolver arranjos de sobrevivências no dia-a-dia para buscar a liberdade ou apenas o sobreviver. A poesia de Joaquim Puerame sobre a negra vendedora de doce revela traços da vida diária das mulheres que realizavam vendas ambulantes pelas ruas da capital alagoana. As vendedoras eram escravas, africanas livres e forras. Na poesia de Jorge de Lima sobre a negra Fulô, encontramos o dia-adia das mulheres negras que realizavam serviços domésticos nas casas de seus senhores. Em ambas as poesias, presenciamos a busca de sobrevivência e/ou resistência da população feminina nas margens da sociedade escravista brasileira do século XIX. Esses serviços, tanto as vendas ambulantes como o trabalho doméstico, poderiam estar ligados à questão da subsistência, mas também era uma forma de constituir pecúlio para quem sonhava em conquistar a liberdade. (DIAS, 1995, p. 126).

Para a historiadora Maria Odila Leite da Silva Dias, que estudou os papéis femininos na São Paulo do século XIX, as vendedoras e quitandeiras "[...] eram como mediadoras e intermediárias, pequenos elos secundários, à sombra dos negócios vultosos, que [...] participavam, assiduamente, das operações do comércio local”. (DIAS, 1995, p. 83). Todavia, esse comércio mal permitia a sobrevivência dessas mulheres, que lutavam diariamente contra a exploração por parte de seus senhores e procuravam formas alternativas para conquistar seus meios de subsistência. (DIAS, 1995, p. 87). Ao estudar a escravidão urbana no Rio de Janeiro, Leila Mezan Algranti se refere a grande quantidade de escravos que eram inseridos nos "[...] trabalhos domésticos, aproveitados como cozinheiros, jardineiros, copeiros e demais 
atividades". (ALGRANTI, 1988, p. 83). Sobre a cidade de Maceió, o historiador Felix Lima Júnior aponta para a presença de escravas "meninas" ou "mocinhas" que:

[...] iam para as cosinhas ou então 'bater roupa' nos fundos dos quintais, as mais afortunadas. Outras, com gamela ou taboleiro na cabeça, percorriam as ruas vendendo peixe, sururu, fressuras, frutas, etc. As mais jeitosas, mais simpáticas, [...] iam trabalhar como copeiras, umas; outras aprendiam a costurar e a bordar, servindo diariamente as Sinhas Moças como mucamas (sic.). (LIMA JUNIOR, 1975, p. 09).

Portanto, eram constantes, na vida das mulheres negras em Maceió, a prestação dos serviços diários descritos acima, sobretudo na região central da cidade, onde ficavam as residências da elite proveniente da economia açucareira da Província. Além disso, as atividades de vendas nas ruas e serviços domésticos eram também um meio para as escravas constituírem "[...] o pecúlio, com que sonhavam comprar a sua alforria". (DIAS, 1995, p. 132). O historiador Luiz Sávio de Almeida, analisando os dados produzidos pelo governo provincial no ano de 1856, nos apresenta a população escrava na capital alagoana dividida por sexo:

População escrava por sexo na freguesia de Maceió, 1856

\begin{tabular}{|l|r|r|r|r|}
\hline Distrito & \multicolumn{5}{|c|}{ Sexo } \\
\hline & \multicolumn{2}{|c|}{ Absoluto } & \multicolumn{2}{c|}{ Relativo } \\
\hline & Masculino & Feminino & Masculino & Feminino \\
\hline Cidade & 421 & 569 & 64,27 & 71,21 \\
\hline Jaraguá & 142 & 127 & 21,68 & 15,89 \\
\hline Poço & 47 & 59 & 7,18 & 7,38 \\
\hline Bebedouro & 45 & 44 & 6,87 & 5,51 \\
\hline Total & 655 & 799 & 100,00 & 100,00 \\
\hline
\end{tabular}

ALMEIDA, Luiz Sávio. Escravidão e Maceió: distribuição espacial e renda em 1856. In: MACIEL, Osvaldo. Pesquisando na Província: economia, trabalho e cultura numa sociedade escravista (Alagoas, século XIX). Maceió: Q Gráfica, 2011, p 94.

Sabemos como é complexo se trabalhar com dados oficiais, sobremaneira nestas pesquisas demográficas que tinham uma forte tendência ao erro, portanto, não a vemos como um espelho da realidade e sim como um resquício para compreendermos o passado. É interessante notar que a quantidade de mulheres escravas era superior à população masculina, tal questão nos remete a pensar sobre o quão era constante a presença delas no quotidiano da cidade de Maceió.

No centro da cidade e no bairro de Jaraguá, onde se situavam as casas dos senhores de engenho, políticos, comerciantes e autoridades, os números de mulheres escravas eram respectivamente de 569 e 127, sendo o número de escravos masculino 421 e 142, o que evidencia 
a presença destas mulheres para realizar tarefas domésticas. Nas cidades brasileiras do Império, os serviços domésticos eram realizados por mulheres, e chamadas de "criadas do servir". (SILVA, 2011, p. 177). Estabelecia-se um grande comércio, o qual pode ser captado nos anúncios dos jornais do século XIX, onde encontramos frequentemente pessoas querendo vender, comprar ou alugar escravas que sabiam cozinhar, engomar, passar, etc.

No dia 24 de janeiro de 1868, o jornal Diário de Alagoas publicava um anúncio no qual se vendia "[...] uma escrava mulata, moça, com uma filha de 3 annos, engoma, lava e cosinha" (sic.) ${ }^{25}$. É interessante notar que as atividades de engomar, lavar e cozinhar poderiam estar associadas a uma mesma escrava, o historiador Maciel Henrique da Silva constatou este fato analisando os jornais do Recife no século XIX. (SILVA, 2011, p. 243). Em anúncio do mesmo jornal no ano de 1870 vendia-se "[...] uma preta de 40 annos com uma filha de onze anos" (sic.) ${ }^{26}$. No jornal $O$ Liberal, o senhor Felino Mascarenhas queria comprar "[...] uma escrava preta, sadia, de bons costumes, e que tenha habilidade para quitandeira”27. Como sinalizou a historiadora Maria de Fatima Novaes Pires: “[...] o abastecimento doméstico para suprir as necessidades alimentares cotidianas devia-se a trabalhos realizados principalmente por mulheres nas cozinhas e quintais das casas" dos seus senhores. (PIRES, 2009, p. 209). Havia também quem desejava apenas alugar escravas, foi o que encontramos no Jornal de Alagoas: "Precisa-se alugar uma preta escrava que saiba cozinhar e engomar, na rua Barão de Jaraguá 14, ou na rua do Saraiva, escritório do Coutinho" ${ }^{28}$. Manuel Diégues Júnior, analisando registros de compra e venda de escravos em Maceió entre os anos de 1873 e 1878, verificou que de 134 vendas, 10 eram de negras cozinheiras e 45 de escravos ligados aos serviços domésticos, sendo o restante destinado ao trabalho na agricultura. (DIÉGUES JUNIOR, 2002, p. 183-184). Para este historiador alagoano:

Como doceira e cozinheira, das melhores aliás, a escrava negra fez sentir sua influência na vida social. Na economia doméstica a contribuição da escrava foi grande. Na culinária em particular. Daí o interesse do que os anúncios de jornais do século passado se referem a escravas como cozinheiras e doceiras. (DIÉGUES JUNIOR, 2002, p. 183).

Todavia, existiam aqueles que queriam escravas para realizar vendas pelas ruas, como em um anúncio encontrado no jornal $O$ Mercantil, que dizia precisar "[...] alugar uma escrava para fazer vendas pelas ruas, quem a tiver e quiser alugar dirija-se a esta typographia que se dirá quem quer" (sic.) ${ }^{29}$. Este aspecto nos faz pensar sobre as escravas de ganho que trabalhavam fora da casa dos seus senhores, sem controle e nem supervisão direta, desenvolviam vendas pelas ruas que auxiliavam a auferir seus ganhos. Como colocou Maria Odila:

25 IHGAL. Diário de Alagoas. 24/01/1868.

${ }^{26}$ IHGAL. Diário de Alagoas. 11/02/1870.

27 IHGAL. O Liberal. 07/06/1878.

${ }^{28}$ IHGAL. Jornal de Alagoas. 05/02/1874.

29 IHGAL. O Mercantil. 13/06/1864. 
Toda sua maneira de sobreviver implicava a liberdade de circulação pela cidade, pois dependiam de um circuito ativo de informações, bate-papos, leva-e-traz, contratos verbais... contra os quais havia medidas de repressão forjadas pelo sistema colonial, envolvendo licenças, toques de recolher, passaportes, salvo-condutos, que afetariam drasticamente, se fossem cumpridas a ferro e fogo, a possibilidade de seu ganha-pão. (DIAS, 1995, p. 73).

Uma das formas mais comuns de se utilizar a escravaria na capital alagoana foi o "ganho", segundo Antônio Daniel, os senhores "[...] incumbiam os seus cativos de realizar tarefas, e, no final de um período acordado, os mesmos deveriam trazer um determinado dinheiro combinado" (RIBEIRO, 2003), sendo mais comum atividades de vendas de alimentos como frutas, sururu e peixes. Em Maceió, tais serviços não eram apenas realizados por escravas, pois as africanas livres também tinham uma forte presença na cidade e eram encarregadas das mesmas tarefas. O Curador dos Africanos Livres de Alagoas, em ofício dirigido ao Presidente da Província no ano de 1855, diz que os africanos:

[...] se prestam pela maior parte nos serviços serventes de obras particulares e do ganho de rua, por se não quererem sujeitar a outros misteres, especialmente as fêmeas, que pela maior parte só se empregam em comércio de quitandeiras. (DUARTE, 1988, p. 63).

Foi o caso da africana livre Benedita, que teve seus serviços arrematados pelo senhor Manoel Claudino d' Arrochela Jaime, no ano de 1850, após ter sido apreendida em uma embarcação de tráfico ilegal de escravos ${ }^{30}$. Todavia, se recusara a prestar serviços domésticos e a residir na casa de seu arrematante. Encontramos tal informação em seu requerimento de emancipação feito no ano de 1861, juntamente com outras duas africanas livres de nomes Joaquina e Maria ${ }^{31}$. Deste modo, ao se recusar a prestar os serviços domésticos na casa de seu arrematante, Benedita "[...] obtivera faculdade para os prestar na rua mercadejando com taboleiro de frutas, e outros generos de legumes, sob a condicão de contribuir hum modico salario" (sic.) ${ }^{32}$ e passou a realizar vendas nas ruas como as mulheres cantadas na poesia de Joaquim Puerame.

Benedita não conseguiu pagar o salário para seu arrematante, pois, se "[...] prohibio por Lei Municipal o uzo de mercadejarem os africanos livres" (sic.)33. Esta postura municipal de Maceió foi aprovada no dia 27 de junho de 1859 e proibia "[...] aos africanos livres de negociarem por si ou por interposta pessoa com gêneros alimentícios de qualquer natureza". (DUARTE, 1988, p. 48). Deste modo, Benedita ficou impedida de realizar suas vendas pelas ruas da cidade, o que fez o seu arrematante exigir que ela voltasse a prestar serviços domésticos na sua residência.

\footnotetext{
${ }^{30}$ APA. Informação sobre req. de Manoel Claudino (Benedita) env. pelo Curador ao Pres. Prov. 17/06/1861. ${ }^{31}$ APA. Informação sobre req. Joaquina, Maria e Benedita env. pelo Curador ao Pres. Prov. 16/05/1861.

${ }^{2}$ APA. Informação sobre req. de Manoel Claudino (Benedita) env. pelo Curador ao Pres. Prov. 17/06/1861.

33 Idem.
} 
Percebemos que as autoridades "[...] procuravam limitar a livre circulação de quitandeiras e vendedoras clandestinas, escravas, forras e africanas livres, fixando-as em locais demarcados da cidade.” Era mais viável a supervisão dos cativos que trabalhavam em serviços domésticos. (DIAS, 1995, p. 126). Talvez por esta questão, na documentação sobre os africanos livres em Maceió, encontramos um maior número de mulheres que eram encarregadas de prestar serviços domésticos, fossem eles nas casas dos arrematantes ou em instituições públicas, como foi o caso da africana livre Roza no hospital de caridade da cidade. Esta foi apreendida em contrabando de africanos nas praias do Morro de Camaragibe em Porto das Pedras, no ano de 1850 - assim como Benedita - e teve seus serviços arrematados por um tenente de nome Bernardo Joaquim Correia que, depois que mudou de domicilio renunciou aos serviços da africana34. Desde então, Roza foi destinada ao "[...] serviço de lavagem de ropas do Hospital de Caridade" (sic.) 35 .

A maioria das africanas livres era destinada a prestar serviços domésticos nas residências de seus arrematantes. Assim aconteceu com Francisca, que prestou serviços a Joaquim Jozé de Almeida36, todavia, ela estava sempre resistindo à condição que lhe era posta. Os arrematantes dos africanos livres os tratavam da mesma forma que os escravos, ocorrendo, um quotidiano de tensões, tentativas de controle e manifestações de resistência. Francisca requereu, em maio de 1861, sua emancipação. Em resposta a tal pedido o curador João Camilo alegou que ela:

Não tem tido hum regular e irreprehensivel comportamento, por que contra ella me tem sido por vezes aprezentadas algumas queixas, e o mesmo arrematante de seus serviços tem ja tentado renuncialos para não ter occaziam de soffrimentos, como elle mesmo me há declarado (sic.) 37 .

Notamos que essas mulheres viveram uma estreita relação com a escravidão, todavia, quiseram, diariamente, afirmar sua condição de livres. A grande quantidade de africanas livres destinadas a prestar serviços domésticos mostrava uma forma de controle social proveniente da hegemonia senhorial, muitas foram às medidas tomadas pelos governantes para inibir qualquer tentativa de insubordinação e desobediência da população cativa. Contudo, sabedoras do momento histórico que viviam, sempre buscaram a emancipação.

O quotidiano das escravas e africanas livres na Maceió do século XIX foi marcado pelo trabalho doméstico e pelos serviços de ganho realizados nas ruas da cidade, principalmente o comércio ambulante. Com isto, elas desenvolviam seus arranjos de sobrevivência e buscavam os caminhos para a liberdade, estes serviços poderiam estar ligados à questão da subsistência, mas também era uma forma de constituir pecúlio para quem sonhava em conquistar a emancipação. Elas eram sabedoras das possibilidades que existiam na conjuntura histórica que viveram e

34 APA. Informação sobre req. João e Luiza env. pelo Curador ao Pres. Prov. 14/03/1851.

35 APA. Requerimento de Carta de Emancipação - João e Luiza. 07/03/1861.

${ }^{36}$ APA. Informação sobre req. Francisca env. pelo Curador ao Pres. Prov. 04/o6/1861.

37 APA. Informação sobre req. Francisca env. pelo Curador ao Pres. Prov. 11/05/1861. 
experimentaram projetos de liberdade. Foram ansiosas e desinquietas pela postergação da solução emancipacionista e manifestaram seus descontentamentos, sejam com movimentos de rebeldia ou buscando os meios legais possíveis entre as brechas da legislação da época.

\section{REFERÊNCIAS BIBLIOGRÁFICAS}

ALMEIDA, Luiz Sávio. Escravidão e Maceió: distribuição espacial e renda em 1856. In: MACIEL, Osvaldo. Pesquisando na Província: economia, trabalho e cultura numa sociedade escravista (Alagoas, século XIX). Maceió: Q Gráfica, 2011.

ALGRANTI, Leila Mezan. O Feitor Ausente: estudo sobre a escravidão urbana no Rio de Janeiro 1808-1822. Petrópolis: Vozes, 1988.

ALMEIDA, Luís Sávio de. Memorial Biográfico de Vicente de Paula, capitão de todas as matas: guerrilha e sociedade alternativa na mata alagoana. Maceió: Edufal. 2008.

ANDRADE, Juliana Alves de. Agricultores, Pretos, Sitiantes e Outras Gentes do Vale: o universal rural das Alagoas na segunda metade do século XIX. In: MACIEL, Osvaldo. Pesquisando na Província: economia, trabalho e cultura numa sociedade escravista (Alagoas, século XIX). Maceió: Q Gráfica, 2011.

ANDRADE, Manoel Correia de. Usinas e Destilarias das Alagoas: uma contribuição ao estudo da produção do espaço. Maceió: Edufal, 1997.

AVÉ-LALLEMENT, Robert. Viagens pelas Províncias da Bahia, Pernambuco, Alagoas e Sergipe. Belo Horizonte, Ed. Itatiaia; São Paulo, Ed. Universidade de São Paulo, 1980.

BARICKMAN, B. J. Até a Véspera: o trabalho escravo e a produção de açúcar nos engenhos do recôncavo baiano (1850-1881). Afro-Ásia, v. 21-22, 1998-99.

BARROS. Theodyr Augusto de. O Processo de Mudança da Capital (Alagoas-Maceió): uma abordagem histórica, 1819-1859. Maceió: Imprensa Universitária, 1991.

BERTIN, Enidelce. Os Meia-cara. Africanos livres em São Paulo no século XIX. USP, 2006, (Tese de Doutorado).

BRANDÃO, Alfredo. Os Negros na História de Alagoas. Maceió: s/ed., 1988.

CARVALHO, Marcus Joaquim Maciel de. Liberdade: rotinas e rupturas do escravismo no Recife, 1822-1850. Recife: Editora Universitária da UFRPE, 2001.

CAVALCANTE, Simone. Literatura em Alagoas. Maceió: Scortecci/ Grafmarques, 2005.

CHALOUB, Sidney. Visões da Liberdade: uma história das ultimas décadas da escravidão na corte. São Paulo: Companhia das Letras, 1990.

CONRAD, Robert. Tumbeiros: o tráfico de escravos para o Brasil. São Paulo: Brasiliense, 1985. COSTA, Craveiro. Maceió. Maceió: Edições Catavento, 2011.

Cunha, Manuela Carneiro da. Olhar Escravo, Ser Olhado. In Azevedo, Paulo Cesar de, e Lissovsky, Mauricio (Orgs.). Escravos brasileiros do século XIX na fotografia de Christiano Jr. São Paulo: ExLibris, 1988.

DIAS. Maria Odila Leite da Silva. Quotidiano e Poder em São Paulo no século XIX. São Paulo: Brasiliense, 1995.

DIEGUES JUNIOR, Manuel. O Bangüê nas Alagoas - Traços da influência do sistema econômico do engenho de açúcar na vida e na cultura regional. $2^{\text {a }}$ edição, Maceió: Edufal: 2002.

DUARTE, Abelardo. Episódios do Contrabando de Africanos nas Alagoas. Maceió: s/ed. 1988. DUARTE, Abelardo. Folclore Negro das Alagoas. Maceió: Edufal, 2010.

DUARTE, Abelardo. População da Vila de Maceió e seu termo no ano de 1827. In: Revista do Instituto Histórico e Geográfico de Alagoas, $\mathrm{n}^{\circ} \mathrm{XXXVI}, 1980$.

EINSEBERG, Peter. Modernização sem Mudança: a indústria açucareira em Pernambuco: 1840-1910. Rio de Janeiro: Paz e Terra, Campinas, Universidade Estadual de Campinas, 1977. ESPÍNDOLA, Thomas do Bom-Fim. Geografia Alagoana ou descrição física, política $e$ histórica da Província das Alagoas. 2 ed. Maceió: Edições Catavento, 2001 [1871].

FORTES, Cynthia Nunes da Rocha. Maceió nos Itinerários de Pedro Nolasco Maciel. In: ALMEIDA, Luiz Sávio (org.) Traços e Troças: literatura e mudança social em Alagoas. Estudos em Homenagem a Pedro Nolasco Maciel. Maceió: Edufal, 2011.

GARDNER, George. Viagem ao Interior do Brasil, principalmente nas províncias do norte do ouro e do diamante durante os anos de 1836-1841. Belo Horizonte, Ed. Itatiaia; São Paulo, Ed. Universidade de São Paulo, 1975. 
KIDDER, Daniel Parish. Reminiscências de Viagens e Permanências nas Províncias do Norte do Brasil. Belo Horizonte: Ed Itatiaia; São Paulo: Ed. Universidade de São Paulo, 1980.

LIMA, Jorge. Poesia Completa. Rio de Janeiro: Nova Fronteira, 2008.

LIMA JUNIOR, Felix. A Escravidão em Alagoas. Maceió: s/ed., 1975.

LIMA Jr., Félix Lima. Carroças e Carroceiros. Maceió, Fundação Teatro Deodoro, 1983.

LINDOSO, Dirceu. A Interpretação da Província: Estudo da Cultura Alagoana. Maceió: Edufal, 2005.

MACIEL, Pedro Nolasco. Traços e Troças (crônica vermelha - leitura quente). $2^{\circ}$ ed. Anotada e comentada por Felix Lima Junior. Maceió: DEC, 1964, [1899].

MATTOSO, Katia M. Ser Escravo no Brasil. São Paulo: Brasiliense, 1982.

MELO. Hélder Silva de. Dados Estatísticos e Escravidão em Alagoas (1850-1872). In: MACIEL, Osvaldo. Pesquisando na Província: economia, trabalho e cultura numa sociedade escravista (Alagoas, século XIX). Maceió: Q Gráfica, 2011.

PIRES, Maria de Fátima Novaes. Fios da Vida: tráfico interprovincial e alforrias nos Sertoins de Sima - BA (1860-1920). São Paulo: Annablume, 2009.

REIS, João José Reis; SILVA, Eduardo. Negociação e Conflito: a resistência negra no Brasil escravista. São Paulo: Companhia das Letras, 1999.

RIBEIRO, Antônio Daniel Marinho. A Transição da Mão-de-obra Escrava para a Livre no Perímetro Urbano de Maceió (1850-1898). Maceió: UFAL, 2003 (Monografia de Graduação em História).

SANTANA. Moacir Medeiros de. Uma Associação Centenária. Maceió: Arquivo Público de Alagoas, 1966.

SANT'ANA, Moacir Medeiros de. Contribuição a História do Açúcar em Alagoas. Recife: Instituto do Açúcar e do Álcool e Museu do Açúcar, 1970.

SILVA, Maciel Henrique. Pretas de Honra: vida e trabalho de domésticas e vendedoras no Recife do século XIX (1840 - 1870). Recife: Ed. Universitária da UFPE. Coedição, Salvador: EDUFBA, 2011.

SILVA, Moíses Sebastião da. Vida na Fronteira: a experiência dos africanos livres em Alagoas (1850-1864). In: MACIEL, Osvaldo. Pesquisando na Província: economia, trabalho e cultura numa sociedade escravista (Alagoas, século XIX). Maceió: Q Gráfica, 2011.

SOARES, Carlos Eugênio Líbano. A Capoeira Escrava e Outras Tradições Rebeldes no Rio de Janeiro (1808-1850). 2a edição, revisada e ampliada. Campinas: Editora UNICAMP/Centro de Pesquisa em História Social da Cultura, 2002.

SOARES, Luiz Carlos. O "Povo de Cam" na Capital do Brasil: a escravidão urbana no Rio de Janeiro do século XIX. Rio de Janeiro: Faperj - 7 letras, 2007.

WISSENBACH, Maria Cortez. Sonhos Africanos, Vivências Ladinas. Escravos e forros em São Paulo (1850-1880). São Paulo: Hucitec, 1998. 